\title{
New species and new records of black fungus gnats (Diptera: Sciaridae) from the Viidumäe Nature Reserve, Estonia
}

\author{
Frank MENZEL ${ }^{1}$, Jukka SALMELA ${ }^{2, *} \&$ Pekka VILKAMAA ${ }^{3}$ \\ ${ }^{1}$ Senckenberg Deutsches Entomologisches Institut, Eberswalder Straße 90, \\ 15374 Müncheberg, Germany. \\ ${ }^{2}$ Regional Museum of Lapland, Arktikum, Pohjoisranta 4, 96200 Rovaniemi, Finland. \\ ${ }^{2}$ Arctic centre, University of Lapland, P.O. Box 122, 96101, Rovaniemi, Finland. \\ ${ }^{3}$ Finnish Museum of Natural History, Zoology Unit, P.O. Box 17, \\ 00014 University of Helsinki, Finland. \\ ${ }^{*}$ Corresponding author: jukka.e.salmela@gmail.com \\ 1Email: frank.menzel@senckenberg.de \\ ${ }^{3}$ Email: pekka.vilkamaa@helsinki.fi \\ ${ }^{1}$ urn:1sid:zoobank.org:author:0F04F9D7-4217-4447-B2A4-650A008EF251 \\ ${ }^{2}$ urn:1sid:zoobank.org:author:D5635C89-AB14-438A-82C8-94E8683A903A \\ ${ }^{3}$ urn:lsid:zoobank.org:author:A4EAD3B5-DA5E-4C09-8E3A-9289CA7358ED
}

\begin{abstract}
An inventory of Sciaridae (Diptera: Sciaroidea) from a eutrophic fen and a spring brook in Viidumäe Nature Reserve (Estonia, Saaremaa Island) recorded a total of 60 species, of which 57 are new records for Estonia, including two that are new to science and described herein as Cratyna (Diversicratyna) palustricola sp. nov. (Estonia) and Sciara bryophila sp. nov. (Estonia, Finland). This has raised the number of Sciaridae known from Estonia from 6 to 63.
\end{abstract}

Keywords. Diptera, Sciaridae, Europe, Estonia, Finland, biodiversity.

Menzel F., Salmela J. \& Vilkamaa P. 2020. New species and new records of black fungus gnats (Diptera: Sciaridae) from the Viidumäe Nature Reserve, Estonia. European Journal of Taxonomy 720: 62-76. https://doi.org/10.5852/ejt.2020.720.1115

\section{Introduction}

Black fungus gnats (Diptera Linnaeus, 1758: Sciaridae Billberg, 1820) are lower Diptera that inhabit most terrestrial habitats, breeding in, for example, decaying wood, leaf detritus and fruiting bodies of fungi (e.g., Menzel \& Mohrig 2000; Vilkamaa \& Komonen 2001), and some species seem to be confined to peat bogs or other moist environments (e.g., Rudzinski 1993; Heller 1998; Salmela \& Vilkamaa 2005). In general, the Sciaridae is a very poorly known family, and undescribed species regularly appear in samples from various parts of the Holarctic region (e.g., Hippa et al. 2003, 2010; Vilkamaa et al. 2013a; Wu et al. 2013; Shi et al. 2014; Heller et al. 2015), even from relatively well-studied Central Europe (Menzel et al. 2003a; Heller \& Menzel 2013). A small number of species may be pests in 
greenhouses or mushroom farms (Menzel et al. 2003b). However, the biology and distribution of most species of the family are insufficiently known.

The knowledge of the sciarid fauna of the Baltic countries is very fragmentary (Kurina et al. 2011, Table 2). For example, only six species in five genera have previously been recorded from Estonia: Chaetosciara estlandica (Lengersdorf, 1929); Corynoptera saetistyla Mohrig \& Krivosheina, 1985; Corynoptera trepida (Winnertz, 1867); Cratyna (Cratyna) uliginosa (Lengersdorf, 1929); Leptosciarella (Leptosciarella) brevipalpa Mohrig \& Menzel, 1992 and Dolichosciara nigrovittata (Strobl, 1910) (Lengersdorf 1929; Mohrig \& Menzel 1994; Menzel \& Mohrig 2000; Heller \& Menzel 2010; Hippa et al. 2010; Vilkamaa et al. 2013b). Here we aim to provide new faunistic information on Sciaridae from Saaremaa Island, Estonia, and to describe two newly detected species.

\section{Material and methods}

Two study sites were selected in Viidumäe Nature Reserve (Estonia, Saaremaa Island, $58.2966^{\circ} \mathrm{N}$, $22.0863^{\circ} \mathrm{E}$ ): a eutrophic fen (Kanna) and a spring brook (Nakimetsa). The Kanna site is an open fen influenced by lime deposits, with a moderate flow of ground water, and occasional dwarf Scots pines (Pinus sylvestris L.). The fen is surrounded by pine-dominated heath forest. The Nakimetsa site is a calcareous spring brook near the Viidumäe esker. The brook flows through a pine forest, almost undisturbed, with occasional broadleaf trees. Spring water values for $\mathrm{pH}(7.86-8.07)$ and conductivity (23.5-41.4 mS/ cm) indicate lime-rich conditions (T. Talvi, pers. com.).

The material was collected using two Malaise traps at each site. Ethylene glycol was used as a preservative in the traps and the material was finally preserved in $70 \%$ ethanol. The traps were in situ from midApril to mid-November 2002, and were emptied at monthly intervals. Sciarids were sorted out from the material and slide-mounted in Euparal. Only males were preserved and studied.

Employed nomenclature and systematics are mainly based on the revision of the Palaearctic fauna (Menzel \& Mohrig 2000), the revision of the Nearctic fauna (Mohrig et al. 2013), and some works after 2000. These comprise Hippa \& Vilkamaa $(2004,2016)$ [Xylosciara, Claustropyga]; Hippa et al. (2003, 2010) [Claustropyga, Corynoptera s. str.]; Mohrig \& Kauschke (2016) [Scatopsciara, in part]; Shin et al. (2019) [Leptosciarella, Mouffetina, Trichosia]; Vilkamaa \& Menzel (2019) [Lycoriella, Hemineurina, Trichocoelina] and Vilkamaa et al. (2004, 2013c) [Dichopygina, Camptochaeta]. The proposal by Mohrig et al. (2017), of Ctenosciara Tuomikoski, 1960 as a junior synonym of Austrosciara Schmitz \& Mjöberg, 1924, was not followed here, because the name-bearing types of the respective type species have not yet been revised and compared.

The examined material, including types, is deposited in the following collections:

MZH $=$ Zoological Museum, Finnish Museum of Natural History, Helsinki, Finland

$\mathrm{LMM}=$ Regional Museum of Lapland, Rovaniemi, Finland

SDEI = Senckenberg Deutsches Entomologisches Institut, Müncheberg, Germany

A $658 \mathrm{bp}$ fragment of cytochrome c oxidase subunit I (COI) was sequenced from two specimens of Sciara bryophila sp. nov. The specimens were placed in $96 \%$ ethanol in a 96-well lysis microplate and dispatched to the Canadian Centre for DNA Barcoding, Biodiversity Institute of Ontario, where DNA was extracted by a non-destructive method and sequenced using standard protocols and primers (deWaard et al. 2008). The new sequences are deposited in GenBank under accession numbers KY200864 and KY200865. 


\section{Results}

\section{Description of new species}

Phylum Arthropoda Latreille, 1829

Class Insecta Linnaeus, 1758

Order Diptera Linnaeus, 1758

Family Sciaridae Billberg, 1820

Genus Cratyna Winnertz, 1867

Cratyna (Diversicratyna) palustricola sp. nov. urn:Isid:zoobank.org:act:4E4B22E3-0BED-4E10-92CD-F121EE7AF3E4

Figs $1-2$

\section{Diagnosis}

Rather small species (wing length $=1.6-1.7 \mathrm{~mm}$ ) with three-segmented palpi. Gonostyli narrowed toward apex, with long apical tooth and 4-6 megasetae. Tegmen conical, broader than long.

\section{Etymology}

The name, a noun in apposition, is derived from the Latin words 'palustris' ('marshy') and '-cola' ('inhabitant'), referring to the habitat of the species.

\section{Material examined}

\section{Holotype}

ESTONIA • ${ }^{\top}$; Saaremaa Island, Viidumäe Nature Reserve; $58.2966^{\circ}$ N, $22.0863^{\circ}$ E; 15 Aug. -11 Sep. 2002; T. Talvi leg; Malaise trap; rich fen; with one male of Corynoptera postforcipata Rudzinski, 1993 on the same slide; MZH.

\section{Paratypes}

ESTONIA • 1 ₹; same collection data as for holotype; 12 Apr.-15 May 2002; with 1 male of Claustropyga brevichaeta (Mohrig \& Antonova, 1978) on the same slide; MZH • 1 गे; same collection data as for holotype; 17 Jul.-15 Aug. 2002; with 2 males of Corynoptera unidentata (Hippa \& Vilkamaa, 1994) on

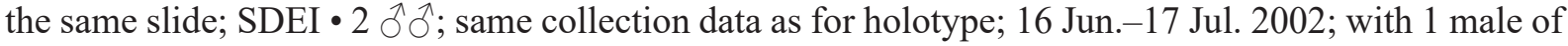
Lycoriella lundstromi (Frey, 1948) on the same slide; MZH.

\section{Description}

\section{Male}

HEAD. Brown. Maxillary palpus very pale brown. Antenna concolorous, pale brown. Eye bridge 3 facets wide. Face with 6 scattered dark setae of various length. Clypeus with 1 dark seta. Maxillary palpus with 3 segments; segment 3 longest, segment 2 shortest; segment 1 with one long sharp seta, with dorsal pit of sensilla. Fourth antennal flagellomere $2.4 \times$ as long as wide, neck shorter than broad; longest setae shorter than width of flagellomere.

ThORAX. Unicolorous brown. Setae dark. Anterior pronotum with 2 setae. Prothoracic episternum with 5-6 setae. Scutellum with 4 long setae and some short setae.

WING. Length $=1.6-1.7 \mathrm{~mm}$. Anal lobe very small. Width $/$ length $=0.35-0.40 . \mathrm{R} 1 / \mathrm{R}=0.60 . \mathrm{c} / \mathrm{W}=$ $0.60-0.75$. r-m shorter than bM, both veins non-setose. Halter pale brown.

Legs. Yellowish. Coxal setae dark. Fore tibial organ with pale vestiture, forming indistinct patch. Fore tibial spur slightly longer than tibial width. 


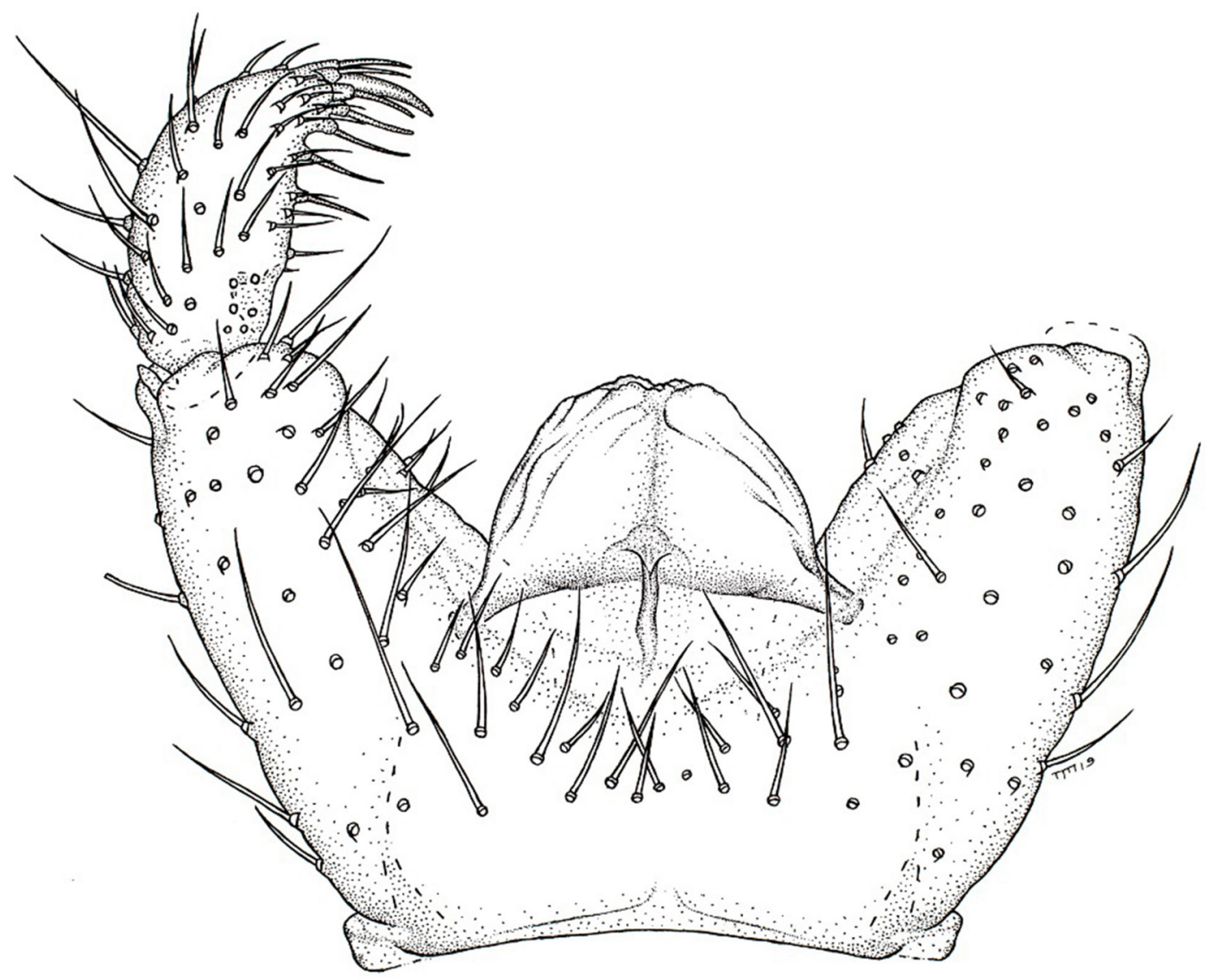

Fig. 1. Cratyna (Diversicratyna) palustricola sp. nov., holotype (MZH), hypopygium, ventral view.

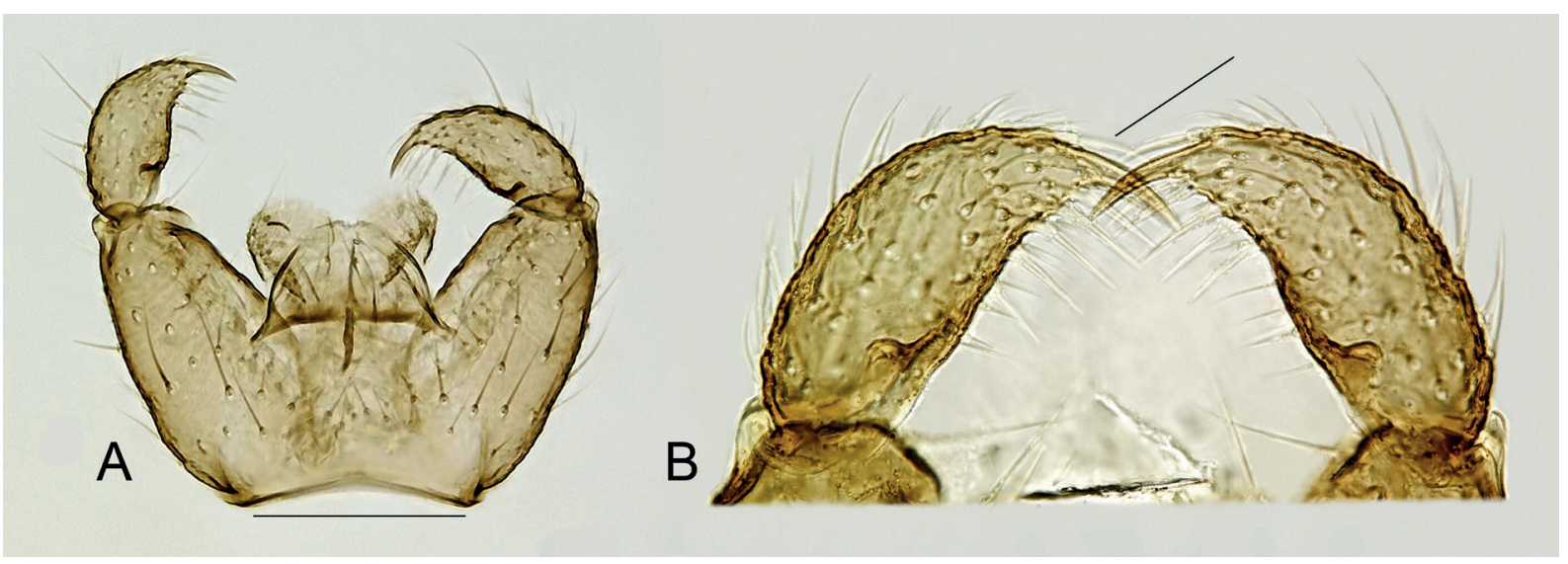

Fig. 2. Cratyna (Diversicratyna) palustricola sp. nov. A. Hypopygium (holotype, MZH), ventral view. B. Gonostyli (paratype, MZH), ventral view. Scale bars: $A=130 \mu \mathrm{m} ; \mathrm{B}=40 \mu \mathrm{m}$. 
Abdomen. Pale brown, paler than thorax. Setae dark and rather short. Hypopygium (Figs 1, 2A) brown, as abdomen. Gonocoxae longer than gonostyli; ventral setosity of gonocoxae normal, sparse. Gonostyli (Figs 1, 2B) elongated, narrowed towards apex, mesial side slightly impressed; setosity sparse; with long apical tooth, with 4-6 megasetae (subequal in size, slender, straight); apically with long curved seta. Tegmen unmodified, conical, broader than long, with small aedeagal teeth; aedeagal apodeme short.

\section{Taxonomic remarks}

Cratyna palustricola sp. nov. belongs to the subgenus Diversicratyna Menzel \& Mohrig, 1998. The new species resembles Cratyna spiculosa (Rudzinski, 1993) and Cr. unispinula (Mohrig \& Menzel, 1992) in having a narrow gonostylus with a long apical tooth and a group of apical and/or subapical megasetae (cf. Rudzinski 1993: 286, figs 11-14; Mohrig \& Menzel 1992: 3, fig. 3a-d). Cratyna palustricola sp. nov. and Cr. unispinula are similar in having the megasetae very narrow (thickened in Cr. spiculosa) and in having the maxillary palpus with three segments (two in Cr. spiculosa). Cratyna palustricola sp. nov. differs from $\mathrm{Cr}$. unispinula in having a broader gonostylus, with its subapical megasetae more numerous (4-7 vs 2) and the basalmost ones placed nearly at the middle of the gonostylus. Furthermore, Cr. palustricola sp. nov. has a modified long seta on the dorsal side of the gonostylus, not a megaseta as Cr. unispinula sometimes does (see Menzel \& Mohrig 2000).

By its gonostylus, Cratyna (Diversicratyna) palustricola sp. nov. resembles Corynoptera salmelai Vilkamaa, Hippa \& Heller, 2013 and Corynoptera spiciforceps Vilkamaa, Hippa \& Heller, 2013. Cratyna palustricola is similar to C. spiciforceps in having the gonostylus evenly narrowed towards apex, whereas $C$. salmelai has it bulged medially. Cratyna palustricola is similar to C. spiciforceps and differs from $C$. salmelai in having the tegmen rounded apically and in having a sensory pit on the $1^{\text {st }}$ palpal segment, whereas $C$. salmelai has sharp apicolateral teeth on its tegmen and the $1^{\text {st }}$ palpal segment with a patch of sensilla. Furthemore, C. spiciforceps has an elongated seta medially on its gonostylus. Cratyna (Diversicratyna) palustricola sp. nov. differs from both species of Corynoptera in having 2 megasetae, not normal setae, on the dorsal side of the apical tooth of the gonostylus, confirming its generic placement.

Genus Sciara Meigen, 1803

Sciara bryophila sp. nov. urn:Isid:zoobank.org:act:DD54A2D5-89FC-448C-914A-95FF4F6FAF52

Figs 3-4

Sciara sp. n. - Salmela \& Vilkamaa 2005: 288, 290 (part of Finnish material).

Sciara sp. A - Salmela et al. 2015: 65, 88 (part of Finnish material).

\section{Diagnosis}

Wing length $2.2-2.7 \mathrm{~mm}$, anal lobe strong. Gonostylus with a strong, densely setose subapical lobe. Setose medial lobe is smaller than the subapical lobe, with (2-4) megasetae, or none. Apical megasetae (5-9) of gonostylus rather short. Tegmen long and conical, apically divided. Aedeagal teeth in a long and narrow area, numerous and evenly short.

\section{Etymology}

The name, a Latin adjective, is derived from the Latinized Greek words 'bryon' ('moss') and 'philo' ('loving'), referring to the mossy habitat of the species. 


\section{Material examined}

\section{Holotype}

FINLAND - ô; Lapponia kemensis pars orientalis, Pelkosenniemi, Sudenvaaranaapa; $67.189^{\circ} \mathrm{N}$, 27.639 ${ }^{\circ}$ E; 28 Jul.-23 Sep. 2014; J. Salmela leg.; Malaise trap; rich fen; in ethanol; BOLD: JSCOI-2016-0161; GenBank: KY200864; LMM NVO.20170727.

\section{Paratypes}

FINLAND • 1 ; ; same collection data as for holotype; in ethanol; BOLD: JS-COI-2016-0162; GenBank: KY200865; LMM NVO.20170728 • 1 §; Ostrobothnia borealis pars borealis, Keminmaa, Kallinkangas; 65.8162 N, 24.5036 E; 27 Jun.-28 Jul. 2014; J. Salmela leg.; Malaise trap; rich fen; in Euparal; JSsl-2015-0001; LMM NVO.20170449 • 1 ○े; same collection data as for preceding; in Euparal; MZH

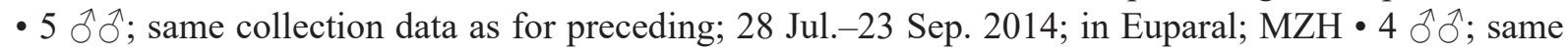
collection data as for preceding; 28 Jul.-23 Sep. 2014; in Euparal; SDEI 2 ô $\hat{\jmath}$; Ostrobothnia borealis pars borealis, Tervola, Karhakkamaa; 66.2031 ${ }^{\circ}$ N, 25.1231 ${ }^{\circ}$ E; 1 Jun.-2 Aug. 2004; J. Salmela leg.; Malaise trap; calcareous rich fen and spring; in Euparal; $\mathrm{MZH} \bullet 1 \mathrm{\delta}$; Ostrobothnia borealis pars borealis, Ylitornio, Palokas; 66.4319 ${ }^{\circ}$ N, $249267^{\circ}$ E; 7-28 Aug. 2017; J. Salmela leg; Malaise trap; rich fen; in ethanol; LMM NVO.20171126 • 1 ○ं; Tavastia borealis, Toivakka, Ruostesuo; $62.0807^{\circ} \mathrm{N}, 25.9070^{\circ} \mathrm{E}$; 1-27 Jul. 2003; J. Salmela leg.; Malaise trap; rich sloping fen; in Euparal; MZH.

ESTONIA • 1 đ̊; Saaremaa Island, Viidumäe Nature Reserve; $58.2966^{\circ}$ N, $22.0863^{\circ}$ E; 14 Jun. -17 Jul. 2002; T. Talvi leg; Malaise trap; rich fen; in Euparal; MZH.

\section{Other material}

FINLAND • 7 §, 2 क; Lapponia kemensis pars orientalis, Pelkosenniemi, Kätkäaapa-Serrijoki; 67.16738 ${ }^{\circ}$ N, $27.8772^{\circ}$ E; 31 Jul.-29 Sep. 2015; J. Salmela leg.; Malaise trap; rich fen;DIPT-JS-2015-0426; LMM NVO.20170572 • 1 o, 1 क ; same collection data as for holotype; DIPT-JS-2016-0002; LMM NVO.20170607.

\section{Description}

\section{Male}

HEAD. Brown, antenna unicolorous, paler brown, maxillary palpus very pale brown. Eye bridge 2-3 facets wide. Face with 18-27 setae, clypeus with 1-5 setae. Maxillary palpus with 3 segments; segments long, segment 3 longest, segment 2 shortest; palpal segment 1 with 6-8 setae, with indistinct dorsal patch of sensilla; body of $4^{\text {th }}$ flagellomere $2.2-3.0 \times$ as long as wide, without distinct apical margin, neck much shorter than broad, sensilla pale and fine, longest sensilla shorter than width of flagellomere.

Thorax. Brown, pleura slightly paler. Setae dark. Anterior pronotum with 3-10 setae. Prothoracal episternum with 7-16 setae. Scutum with short dorsocentrals, with some longer and shorter laterals, scutellum with more than 4 long setae, and some short setae.

WING. Fumose brown. Length $=2.2-2.7 \mathrm{~mm}$. Width $/$ length $=0.45$. Anal lobe strong. Veins distinct. $\mathrm{R} 1 / \mathrm{R}=1.1-1.65 . \mathrm{c} / \mathrm{w}=0.55-0.75 . \mathrm{r}-\mathrm{m}$ subequal with $\mathrm{bM}$. $\mathrm{M}$ and $\mathrm{CuA}$ setose, stM with some setae, $\mathrm{r}-\mathrm{m}$ non-setose or with 1-7 setae, bM non-setose or rarely with 1 seta.

Legs. Pale brown, coxae darker. Coxal setae dark. Fore tibial organ with pale and fine vestiture forming large subtriangular patch. Fore tibial spur as long as tibial width. Hind tibia without spinose setae. Claws without teeth.

ABDomen. Brown, slightly paler than thorax. Setae dark, strong and rather long. Hypopygium (Figs 3A, 4) brown, concolorous with abdomen. Gonocoxae short and broad, nearly as long as gonostyli, mesial 
margin with sparse setosity. Gonostylus (Fig. 3B) with 5-9 megasetae apically (average 7 by $n=13$ ), with richly setose subapical lobe and small densely setose medial lobe with $0-4$ strong megasetae on its apical side (0 in southern populations, i.e., Estonia and Toivakka (Fig. 4), 2-4 megasetae present in northern populations). Tegmen long and conical, apically with indistinctly divided medial process, ventrally with narrow elongated area of small aedeagal teeth, all aedeagal teeth numerous and evenly short; aedeagal apodeme sclerotised and very short.

\section{Taxonomic remarks}

Sciara bryophila sp. nov. belongs to the Sciara humeralis group in the sense of Menzel \& Mohrig (2000). These have a basically triangular gonostylus, strongly impressed and narrowed towards the apex, with strong megasetae (spines) which in some species are arranged in a long and narrow apical group on a common basal projection, and a basal, densely setose lobe. Although there is some variation between the specimens of Sciara bryophila sp. nov. from different localities, for example, the specimens from northern Finland have stronger gonostylar megasetae than the central Finnish and Estonian specimens, we regard all as conspecific.

Sciara bryophila sp. nov. is similar to S. multispinulosa Mohrig \& Kozánek, 1992 - described from North Korea in Mohrig et al. (1992: 19, fig. 1a-c) and redescribed by Sutou et al. (2004: 185, fig. 6a-b) on the basis of Japanese material - and S. kitakamiensis Sutou, 2004 described from Japan in Sutou et al. (2004: 186, fig 7a-d). The mentioned three species have the gonostylus dorsally strongly impressed with a dorsobasal short lobe and a stronger ventral lobe with short, curved spine-like setae and the apex with strong megasetae, two of which are placed on a common basal body dorsally in the subapical part. Sciara bryophila sp. nov. is similar to S. kitakamiensis in having the ventral lobe of the gonostylus in the apical half of the gonostylus, and the gonostylus with only 9 strong megasetae, whereas $S$. multispinulosa has the ventral lobe at the middle of the gonostylus, and the gonostylus with 15-18 weak megasetae. Sciara bryophila sp. nov. is similar to S. multispinulosa and differs from S. kitakamiensis in having its
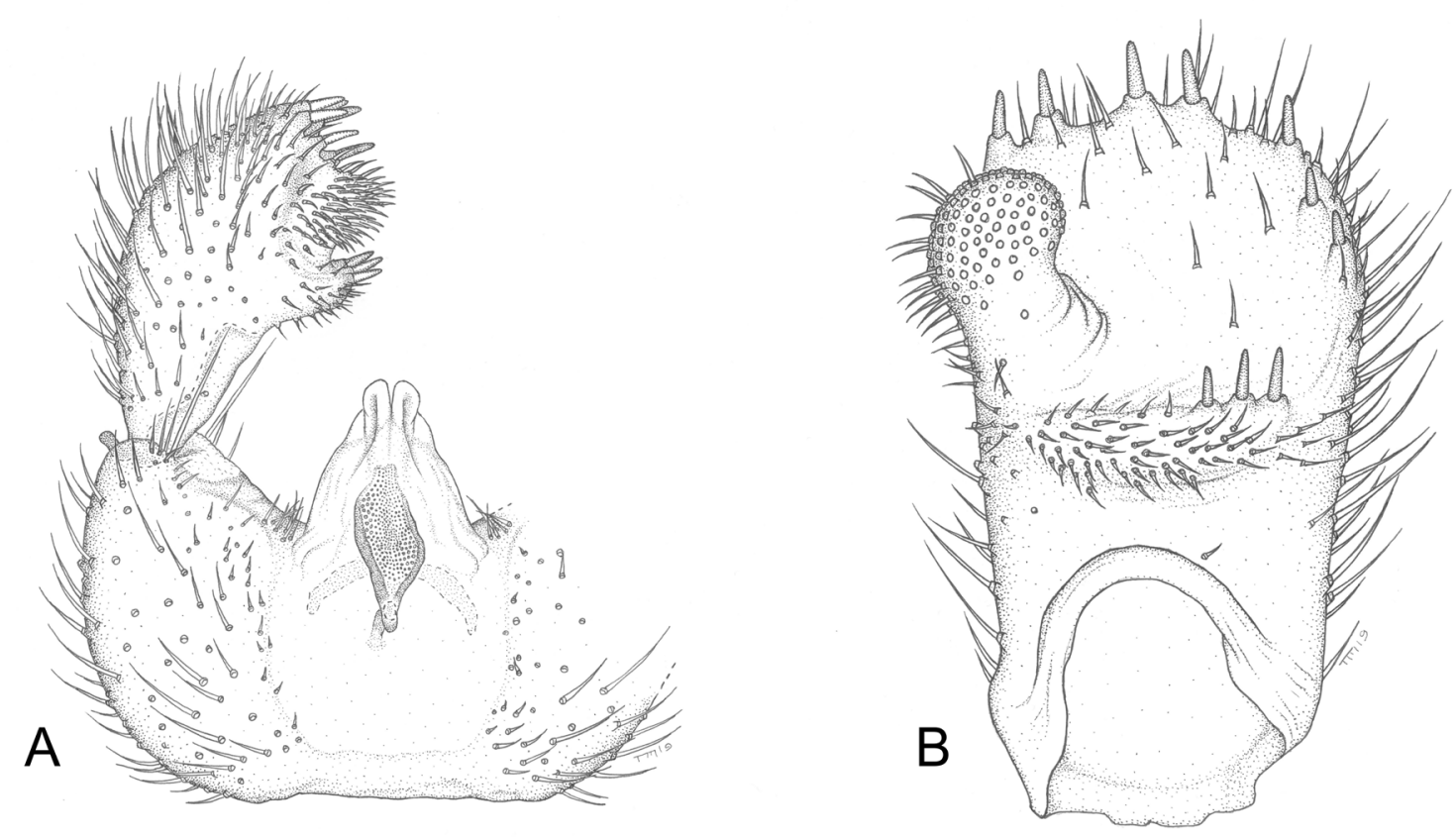

Fig. 3. Sciara bryophila sp. nov., holotype (LMM NVO.20170727). A. Hypopygium, ventral view. B. Gonostylus, mesial view. 
gonostylus ventrally more impressed, its dorsal lobe more prominent and the dorsosubapical pair of setae much longer than their common base. Furthermore, S. bryophila sp. nov. differs from S. kitakamiensis in having the apical megasetae of the gonostylus separate, not placed in a common long basal projection, and in having the ventral lobe less apical in position and in having a few megasetae on the apical side of the ventral lobe (S. kitakamiensis has the ventral lobe nearly apical in position and has no megasetae on its dorsal side).

\section{DNA analyses}

In the BOLD (Ratnasingham \& Hebert 2007) database, the present barcodes cluster in a unique BIN (Barcode Index Number, BOLD:ADD2461), shared by no other specimens. The closest specimen in BOLD is 3.29\% distant (K2P) from the sequenced type specimens, and the closest BIN(BOLD:ADD2588) is mainly composed of specimens belonging to S. humeralis Zetterstedt, 1851.

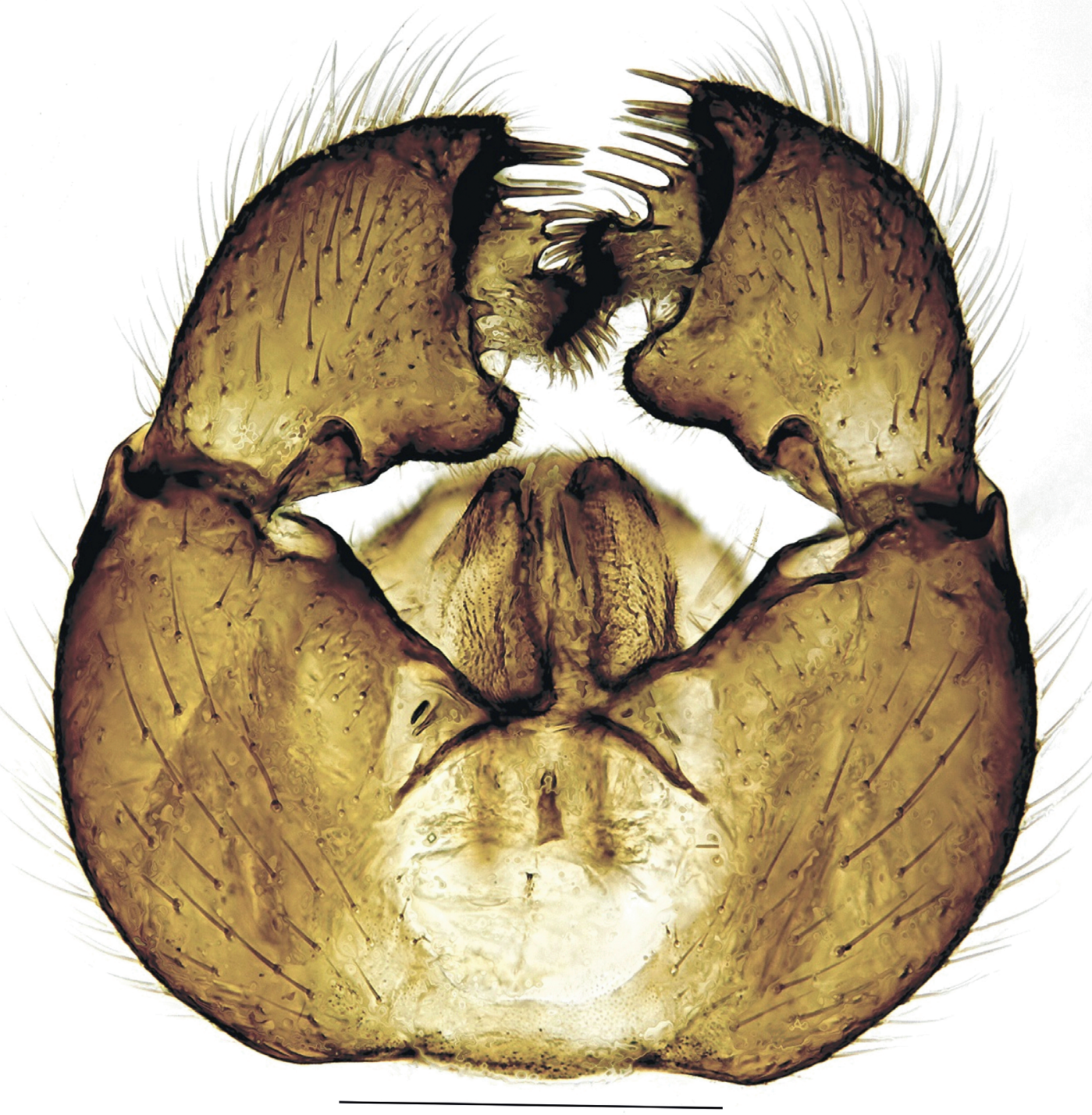

Fig. 4. Sciara bryophila sp. nov., paratype from Estonia, Viidumäe (MZH), hypopygium, ventral view. Scale bar $=300 \mu \mathrm{m}$. 


\section{Ecology and distribution}

The new species occurs in rich fens, that is, in peatlands dominated by brown mosses and characterised by $\mathrm{pH}$ values around 7 or even above. In Finland the species occurs from south boreal to north boreal zones, but in South Finland it is known only from one site (Toivakka). It is assumed that S. bryophila sp. nov. is a rare or relict-like species in the hemiboreal and south boreal zones, being more common in mid and north boreal zones, especially in areas with limestone or calcareous bedrock. There are no records from the subalpine zone and the species may be absent from the northernmost parts of Fennoscandia.

\section{Faunistics}

A relatively high number of new species and species new for the Estonian fauna were recorded from a rather small number of studied specimens $(\mathrm{n}=225)$. Corynoptera saetistyla (24 specimens), C. verrucifera (Lengersdorf, 1952) (17 specimens), Cratyna nobilis (Winnertz, 1867) (17 specimens), Camptochaeta camptochaeta (Tuomikoski, 1960) (13 specimens) and Corynoptera postforcipata Rudzinski, 1993 (12 specimens) were most numerous. Most of the detected sciarid species are known from Central and/or Northern Europe, while many of them are common and widespread in the Palaearctic region. The sciarid species recorded in the Viidumäe Nature Reserve from April to November 2002 with four Malaise traps are listed in Table 1.

\section{Discussion}

A total of 225 individuals belonging to 60 species were identified, of which Cratyna palustricola sp. nov. and Sciara bryophila sp. nov. are new to science. Of the 60 species collected in the Viidumäe Nature Reserve, only three were already known from other localities in Estonia: Corynoptera saetistyla, Corynoptera trepida and Cratyna uliginosa. Thus, 57 sciarid species are here recorded for the first time from Estonia, including the two previously undescribed species (Table 1). The previously identified species Chaetosciara estlandica, Leptosciarella brevipalpa and Dolichosciara nigrovittata were not found in our study, which may be due to the habitat structure of the collected areas and/or the trapping method used. Consequently, 63 sciarid species are currently known from Estonia. They are spread over 19 genera as follows: Bradysia Winnertz, 1867 (7 species); Camptochaeta Hippa \& Vilkamaa, 1994 (3); Chaetosciara Frey, 1942 (1); Claustropyga Hippa, Vilkamaa \& Mohrig, 2003 (2); Corynoptera Winnertz, 1867 (14); Cratyna Winnertz, 1867 (5); Ctenosciara Tuomikoski, 1960 (1); Dichopygina Vilkamaa, Hippa \& Komarova, 2004 (2); Dolichosciara Tuomikoski, 1960 (3); Leptosciariella Tuomikoski, 1960 (4); Lycoriella Frey, 1942 (4); Mouffetina Frey, 1942 (1); Prosciara Frey, 1942 (1); Pseudolycoriella Menzel \& Mohrig, 1998 (1); Scatopsciara Edwards, 1927 (5); Sciara Meigen, 1803 (2); Scythropochroa Enderlein, 1911 (1); Trichosia Winnertz, 1867 (4); Xylosciara Tuomikoski, 1957 (2).

Faunistically significant are Camptochaeta sicilicula Hippa \& Vilkamaa, 1994, Corynoptera marinae Mohrig \& Mamaev, 1986, Corynoptera subtetrachaeta Komarova, 1995 and Dolichosciara saetosa (Lengersdorf, 1929). Only one individual of each of these rare species was captured in the Viidumäe Nature Reserve during an entire vegetation period. Furthermore, only a few specimens of these four species exist in collections, and they have been found in very few places in Europe.

Our results have revealed that the sciarid fauna of Estonia is very poorly known so far. The new faunistic records clearly reflect the lack of previous studies rather than a large sampling effort in the present study. This is supported by the comparison of the previously known species inventory of the Baltic States with that of the Fennoscandian countries (Table 2). Currently only 63 species are known from Estonia, 28 from Latvia and 22 from Lithuania. The Fennoscandian fauna is much better studied (Norway $=143$ species; Sweden $=299$ species; Finland $=370$ species). About 450 to 500 sciarid species are expected for the fauna of Fennoscandia and at least 300 for the Baltic States. 
Table 1 (continued on the next page). Sciaridae Billberg, 1820 collected from Viidumäe Nature Reserve in Estonia. Material from Kanna and Nakimetsa are combined. Abbreviations: $*=$ First record from Estonia. Collecting periods: $\mathbf{1}=12$ Apr.-15 May 2002; $\mathbf{2}=15$ May-16 Jun. 2002; 3 = 16 Jun. -17 Jul. 2002; 4 = 17 Jul.-15 Aug. 2002; 5 = 15 Aug.-11 Sep. 2002; 6 = 11 Sep.-17 Nov. 2002. Subgenera: Bae. $=$ Baeosciara $;$ Cra.$=$ Cratyna s. str.; Div. $=$ Diversicratyna $;$ Lep.$=$ Leptosciarella s. str.; Sca. $=$ Scatopsciara s. str.; Spa. $=$ Spathobdella $;$ Tri. $=$ Trichosia s. str.; Xen. $=$ Xenopygina $;$ Xyl. $=$ Xylosciara s. str.

\begin{tabular}{|c|c|c|c|c|c|c|}
\hline \multirow{2}{*}{ Species } & \multicolumn{6}{|c|}{ Collecting periods } \\
\hline & 1 & 2 & 3 & 4 & 5 & 6 \\
\hline Bradysia aprica (Winnertz, 1867) * & 1 & & 2 & & 2 & \\
\hline Bradysia brevispina Tuomikoski, 1960 * & & & 1 & & & \\
\hline Bradysia pectoralis (Staeger, 1840) * & & & 1 & & & \\
\hline Bradysia regularis (Lengersdorf, 1934) * & & 1 & & & & \\
\hline Bradysia submoesta Mohrig \& Krivosheina, 1989 * & 1 & 1 & 2 & & 1 & \\
\hline Bradysia tilicola (Winnertz, 1867) * & & & 1 & & & \\
\hline Bradysia trivittata (Staeger, 1840) * & 1 & & 1 & & & \\
\hline Camptochaeta camptochaeta (Tuomikoski, 1960) * & 8 & 5 & & & & \\
\hline Camptochaeta coei (Freeman, 1983) * & 1 & & & & & \\
\hline Camptochaeta sicilicula Hippa \& Vilkamaa, 1994 * & & 1 & & & & \\
\hline Claustropyga brevichaeta (Mohrig \& Antonova, 1978) * & 5 & & & & & \\
\hline Claustropyga heteroclausa (Rudzinski, 1991) * & 1 & & & & & \\
\hline Corynoptera barbata Tuomikoski, 1960 * & & & & & 1 & \\
\hline Corynoptera boletiphaga (Lengersdorf, 1940) * & 1 & & 1 & & & \\
\hline Corynoptera forcipata (Winnertz, 1867) * & & 1 & 3 & & & 1 \\
\hline Corynoptera irmgardis (Lengersdorf, 1940) * & 4 & & 1 & & & 1 \\
\hline Corynoptera marinae Mohrig \& Mamaev, 1986 * & & & & & 1 & \\
\hline Corynoptera melanochaeta Mohrig \& Menzel, 1992 * & & & 1 & & & \\
\hline Corynoptera postforcipata Rudzinski, 1993 * & & 1 & 9 & & 2 & \\
\hline Corynoptera saetistyla Mohrig \& Krivosheina, 1985 & & & 16 & & 8 & \\
\hline Corynoptera sphenoptera Tuomikoski, 1960 * & 2 & & 1 & & 1 & 1 \\
\hline Corynoptera subtetrachaeta Komarova, 1995 * & 1 & & & & & \\
\hline Corynoptera trepida (Winnertz, 1867) & 2 & 3 & 1 & & & \\
\hline Corynoptera tridentata Hondru, 1968 * & & & & & 1 & \\
\hline Corynoptera unidentata (Hippa \& Vilkamaa, 1994) * & & & 1 & 2 & & \\
\hline Corynoptera verrucifera (Lengersdorf, 1952) * & 12 & 5 & & & & \\
\hline Cratyna (Cra.) uliginosa (Lengersdorf, 1929) & & 1 & & & & \\
\hline Cratyna (Div.) spiculosa (Rudzinski, 1993) * & & 1 & & & 1 & 1 \\
\hline Cratyna (Div.) palustricola sp. nov.* & 1 & & 2 & 1 & 1 & \\
\hline Cratyna (Spa.) falcifera (Lengersdorf, 1933) * & & 1 & 3 & & 3 & \\
\hline Cratyna (Spa.) nobilis (Winnertz, 1867) * & 12 & 1 & 1 & & 3 & \\
\hline Ctenosciara hyalipennis (Meigen, 1804) * & 5 & 3 & & & & \\
\hline Dichopygina nigrohalteralis (Frey, 1948) * & 1 & 1 & & & & \\
\hline Dichopygina ramosa Vilkamaa, Hippa \& Komarova, 2004 * & 2 & & & & & \\
\hline Dolichosciara ornata (Winnertz, 1867) * & & 5 & & & & 3 \\
\hline
\end{tabular}


Table 1 (continued). Sciaridae Billberg, 1820 collected from Viidumäe Nature Reserve in Estonia. Material from Kanna and Nakimetsa are combined. Abbreviations: * = First record from Estonia. Collecting periods: $\mathbf{1}=12$ Apr.-15 May 2002; $2=15$ May-16 Jun. 2002; $3=16$ Jun.-17 Jul. 2002; 4 = 17 Jul. -15 Aug. 2002; 5 = 15 Aug. -11 Sep. 2002; 6 =11 Sep. -17 Nov. 2002. Subgenera: Bae. = Baeosciara $;$ Cra. $=$ Cratyna s. str.; Div. $=$ Diversicratyna $;$ Lep.$=$ Leptosciarella s. str.; Sca.$=$ Scatopsciara s. str.; Spa. $=$ Spathobdella; Tri. $=$ Trichosia s. str.; Xen. $=$ Xenopygina $;$ Xyl. $=$ Xylosciara s. str.

\begin{tabular}{|c|c|c|c|c|c|c|}
\hline \multirow{2}{*}{ Species } & \multicolumn{6}{|c|}{ Collecting periods } \\
\hline & 1 & 2 & 3 & 4 & 5 & 6 \\
\hline Dolichosciara saetosa (Lengersdorf, 1929) * & & & 1 & & & \\
\hline Leptosciariella (Lep.) fuscipalpa (Mohrig \& Mamaev, 1979) * & 2 & & & & & \\
\hline Leptosciariella (Lep.) subpilosa (Edwards, 1925)* & & & & & 1 & \\
\hline Leptosciariella (Lep.) viatica $($ Winnertz, 1867) * & 2 & & & & & \\
\hline Lycoriella ingenua (Dufour, 1839) * & & & 1 & & & \\
\hline Lycoriella latilobata Menzel \& Mohrig, 2000 * & & 1 & & & & \\
\hline Lycoriella lundstromi (Frey, 1948) * & & & 1 & & & \\
\hline Lycoriella minutula Mohrig \& Krivosheina, 1987 * & & 1 & 1 & & & \\
\hline Mouffetina pulchricornis (Edwards, 1925) * & & & & & 1 & \\
\hline Prosciara prosciarioides (Tuomikoski, 1960) * & 2 & & 2 & & 4 & \\
\hline Pseudolycoriella subbruckii (Mohrig \& Hövemeyer, 1992) * & & 2 & 2 & & 4 & \\
\hline Scatopsciara (Sca.) atomaria (Zetterstedt, 1851)* & & 1 & & & & \\
\hline Scatopsciara (Sca.) calamophila Frey, 1948 * & 1 & & & & & \\
\hline Scatopsciara (Sca.) neglecta Menzel \& Mohrig, 1998 * & & & 1 & & & \\
\hline Scatopsciara (Sca.) pusilla (Meigen, 1818) * & & & & & 1 & \\
\hline Scatopsciara (Xen.) vagula Tuomikoski, $1960 *$ & 1 & & & & & \\
\hline Sciara bryophila sp. nov. * & & & 1 & & & \\
\hline Sciara hebes (Loew, 1869)* & & & 1 & & & \\
\hline Scythropochroa radialis Lengersdorf, $1926 *$ & & & & & 1 & \\
\hline Trichosia (Bae.) scotica (Edwards, 1925) * & 1 & & & & & \\
\hline Trichosia (Tri.) acrotricha Tuomikoski, $1960 *$ & & & & & 1 & \\
\hline Trichosia (Tri.) caudata (Walker, 1848) * & 6 & 2 & & & & \\
\hline Trichosia (Tri.) confusa Menzel \& Mohrig, 1997 * & 1 & & & & & \\
\hline Xylosciara (Xyl.) microdon (Frey, 1948) * & 1 & & & & & \\
\hline Xylosciara $($ Xyl. $)$ spectabilis Rudzinski, $1992 *$ & 1 & 1 & & & & \\
\hline
\end{tabular}

The high number of identified species, the two newly described species and the high proportion of species that were newly recorded for the Estonian fauna show that even relatively small field studies can make a major contribution to biodiversity research. However, the discovery of new and faunistically interesting species shows also that mires, eutrophic fens and spring water-influenced habitats may provide new insights into sciarid ecology and taxonomy, and that they are worth protecting. 
Table 2. Numbers of genera and species of Sciaridae Billberg, 1820 in Fennoscandia and the Baltics. Remark: countries are listed according to their geographical location from north-west (NW) to southeast (SE).

\begin{tabular}{|c|c|c|c|c|}
\hline \multirow{2}{*}{ Region } & \multirow{2}{*}{ Countries } & \multicolumn{2}{|c|}{ Number of } & \multirow{2}{*}{ References } \\
\hline & & genera & species & \\
\hline \multirow{3}{*}{ 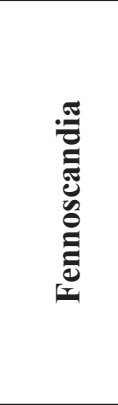 } & Norway & 22 & 143 & $\begin{array}{l}\text { Heller \& Menzel (2010); Vilkamaa \& Menzel (2019); Menzel } \\
\text { et al. (2020) } \\
\text { [including Jan Mayen and Svalbard] }\end{array}$ \\
\hline & Sweden & 28 & 299 & $\begin{array}{l}\text { Heller et al. (2009, 2015, 2016); Heller \& Menzel (2010, } \\
\text { 2013); Vilkamaa et al. (2013a, 2013c, 2013d); Vilkamaa \& } \\
\text { Menzel (2019) }\end{array}$ \\
\hline & Finland & 29 & 370 & $\begin{array}{l}\text { Heller \& Menzel (2010); Vilkamaa (2014); Heller et al. } \\
\text { (2015); Salmela et al. (2015); Hippa \& Vilkamaa (2016); } \\
\text { Vilkamaa \& Menzel (2019) }\end{array}$ \\
\hline \multirow{3}{*}{ 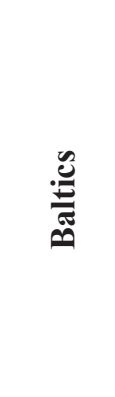 } & Estonia & 19 & 63 & $\begin{array}{l}\text { Lengersdorf (1929); Mohrig \& Menzel (1994); Menzel \& } \\
\text { Mohrig (2000); Heller \& Menzel (2010); Hippa et al. (2010); } \\
\text { Vilkamaa et al. (2013b); this study }\end{array}$ \\
\hline & Latvia & 10 & 28 & $\begin{array}{l}\text { Mohrig et al. (1985); Menzel (1992); Mohrig (1993); } \\
\text { Mohrig \& Menzel (1993, 1994, 1997); Menzel \& Mohrig } \\
\text { (1997, 2000); Heller \& Menzel (2010); Hippa } \text { et al. (2010) }\end{array}$ \\
\hline & Lithuania & 10 & 22 & $\begin{array}{l}\text { Mohrig \& Menzel (1993); Pakalniškis et al. (2000, 2006); } \\
\text { Podènas \& Pakalniškis (2000); Heller \& Menzel (2010); } \\
\text { Kurina et al. (2011) }\end{array}$ \\
\hline
\end{tabular}

\section{Acknowledgements}

We are greatly indebted to Dr Tõny Talvi (Viidumäe Nature Reserve, Estonia) for running the Malaise traps in the field in 2002. Tanja Männistö (Rovaniemi, Finland) is thanked for illustrations and Andrew Liston (SDEI, Müncheberg, Germany) for checking the English. Comments by four referees improved the manuscript.

\section{References}

deWaard J., Ivanova N., Hajibabaei M., Hebert P.D.N. 2008. Assembling DNA Barcodes. In: Martin C. (ed.) Environmental Genomics: 275-293. Methods in Molecular Biology 410. Humana Press Inc. https://doi.org/10.1007/978-1-59745-548-0_15

Heller K. 1998. Beiträge zur Sciaridenfauna Schleswig-Holsteins (Diptera). Teil 1. Das Trentmoor bei Plön. Dipteron 1: 45-56.

Heller K. \& Menzel F. 2010. Fauna Europaea: Sciaridae. In: Beuk P.L.T. \& Pape T. (eds) Fauna Europaea: Diptera, Nematocera. Fauna Europaea Version 2.3. Available from http://www.faunaeur.org [accessed 22 Jun. 2016].

Heller K. \& Menzel F. 2013. Drei neue Trauermückenarten aus Mitteleuropa (Diptera: Sciaridae). In: Weber D. (ed.) Die Höhlenfauna Luxemburgs: 337-348. Ferrantia 69. Musée national d'histoire naturelle du Luxembourg, Luxembourg.

Heller K., Vilkamaa P. \& Hippa H. 2009. An annotated check list of Swedish black fungus gnats (Diptera, Sciaridae). Sahlbergia 15: 23-51. 
Heller K., Hippa H. \& Vilkamaa P. 2015. Taxonomy of Bradysia Winnertz (Diptera, Sciaridae) in the Northern Holarctic, with the description of four new species. European Journal of Taxonomy 122: 1-15. https://doi.org/10.5852/ejt.2015.122

Heller K., Köhler A., Menzel F., Olsen K.M. \& Gammelmo Ø. 2016. Two formerly unrecognized species of Sciaridae (Diptera) revealed by DNA barcoding. Norwegian Journal of Entomology 63: 96-115.

Hippa H. \& Vilkamaa P. 2004. The genus Xylosciara Tuomikoski (Diptera, Sciaridae): phylogeny and review of the species. Acta Zoologica Fennica 214: 1-38.

Hippa H. \& Vilkamaa P. 2016. New species of Claustropyga Hippa, Vilkamaa \& Mohrig (Diptera, Sciaridae) from the Holarctic region. Zootaxa 4088 (4): 594-600.

https://doi.org/10.11646/zootaxa.4088.4.10

Hippa H., Vilkamaa P. \& Mohrig W. 2003. Phylogeny of Corynoptera Winnertz and related genera, with the description of Claustropyga gen. nov. (Diptera, Sciaridae). Studia dipterologica 9 (2) (2002): 469-511.

Hippa H., Vilkamaa P. \& Heller K. 2010. Review of the Holarctic Corynoptera Winnertz, 1867, s. str. (Diptera, Sciaridae). Zootaxa 2695: 1-197. https://doi.org/10.11646/zootaxa.2695.1.1

Kurina O., Vilkamaa P. \& Rimsaite J. 2011. Eleven species of Sciaroidea (Diptera) new to the Lithuanian fauna. New and Rare for Lithuania Insect Species 23: 101-105.

Lengersdorf F. 1929. Die Sciariden (Trauermücken) des Zehlaubruches. Schriften der physikalischökonomischen Gesellschaft zu Königsberg 66 (2): 313-319.

Menzel F. 1992. Beiträge zur Taxonomie und Faunistik der paläarktischen Trauermücken (Diptera, Sciaridae). Teil II. Die Sciaridae des Museums für Naturkunde der Humboldt-Universität zu Berlin. Beiträge zur Entomologie 42 (2): 259-277. https://doi.org/10.21248/contrib.entomol.42.2.259-277

Menzel F. \& Mohrig W. 1997. Revision der paläarktischen Arten von Trichosia Winnertz sensu Tuomikoski, 1960 (Diptera, Sciaridae). - Teil I. Gattung Trichosia Winnertz, 1867. Studia dipterologica 4 (1): 3-40.

Menzel F. \& Mohrig W. 2000. Revision der paläarktischen Trauermücken (Diptera: Sciaridae). Studia dipterologica Supplement 6 (1999): 1-761, Ampyx-Verlag, Halle an der Saale.

Menzel F., Gammelmo Ø., Olsen K.M. \& Köhler A. 2020. The black fungus gnats (Diptera: Sciaridae) of Norway - Part I: species records published until December 2019, with an updated checklist. ZooKeys 957: 17-104. https://doi.org/10.3897/zookeys.957.46528

Menzel F., Schulz U. \& Taeger T. 2003a. Neue Trauermücken aus dem nordostdeutschen Tiefland, mit einer ökologischen Betrachtung von Wurzelteller-Fängen und einer Checkliste der aus Berlin/ Brandenburg bekannten Arten (Diptera: Sciaridae). Beiträge zur Entomologie 53 (1): 71-105.

https://doi.org/10.21248/contrib.entomol.53.1.71-105

Menzel F., Smith J.E. \& Colauto N.B. 2003b. Bradysia difformis Frey and Bradysia ocellaris (Comstock): two additional Neotropical species of black fungus gnats (Diptera: Sciaridae) of economic importance: a redescription and review. Annals of the Entomological Society of America 96 (4): 448-457.

https://doi.org/10.1603/0013-8746(2003)096[0448:BDFABO]2.0.CO;2

Mohrig W. 1993. Der Artenkreis Corynoptera concinna (Winnertz 1867) (Diptera, Sciaridae). Bonner zoologische Beiträge 44 (1-2): 47-55.

Mohrig W. \& Kauschke E. 2016. New black fungus gnats (Diptera, Sciaridae) of North America. Part I. Genus Scatopsciara Edwards, 1927. Zootaxa 4150 (4): 401-435.

https://doi.org/10.11646/zootaxa.4150.4.3 
Mohrig W. \& Menzel F. 1992. Neue Arten europäischer Trauermücken (Diptera, Sciaridae). An International Journal of Dipterological Research 3 (1-2): 1-16.

Mohrig W. \& Menzel F. 1993. Revision der paläarktischen Arten der Bradysia brunnipes-Gruppe (Diptera, Sciaridae). Bonner zoologische Beiträge 44 (3-4): 267-291.

Mohrig W. \& Menzel F. 1994. Revision der paläarktischen Arten von Phytosciara Frey (Diptera: Sciaridae). Beiträge zur Entomologie 44 (1): 167-210.

Mohrig W. \& Menzel F. 1997. Revision der paläarktischen Arten von Trichosia Winnertz sensu Tuomikoski, 1960 (Diptera, Sciaridae). Teil II. Gattungen Leptosciarella Tuomikoski, 1960 und Trichodapus gen. nov. Studia dipterologica 4 (1): 41-98.

Mohrig W., Krivosheina N. \& Mamaev B. 1985. Beiträge zur Kenntnis der Trauermücken (Diptera, Sciaridae) der Sowjetunion. Teil VIII. Neue Arten aus europäischen Gebieten. Zoologische Jahrbücher, Abteilung für Systematik, Ökologie und Geographie der Tiere 112 (3): 299-310.

Mohrig W., Menzel F. \& Kozánek M. 1992. Neue Trauermücken (Diptera, Sciaridae) aus Nord-Korea und Japan. An International Journal of Dipterological Research 3 (1-2): 17-32.

Mohrig W., Heller K., Hippa H., Vilkamaa P. \& Menzel F. 2013. Revision of black fungus gnats (Diptera: Sciaridae) of North America. Studia dipterologica 19 (1-2) (2012): 141-286.

Mohrig W., Kauschke E. \& Heller K. 2017. Austrosciara Schmitz \& Mjöberg, 1924, a senior synonym of Ctenosciara Tuomikoski, 1960 (Diptera: Sciaridae) and the description of a new brachypterous species in the genus. Zootaxa 4344 (2): 357-366. https://doi.org/10.11646/zootaxa.4344.2.10

Pakalniškis S., Rimšaitè J., Sprangauskaitė-Bernotienè R., Butautaitè R. \& Podėnas S. 2000. Checklist of Lithuanian Diptera. Acta Zoologica Lituanica 10 (1): 3-58.

https://doi.org/10.1080/13921657.2000.10512316

Pakalniškis S., Bernotienė R., Lutovinovas E., Petrašiūnas A., Podėnas S., Rimšaitė J., Sæther O.A. \& Spungis V. 2006. Checklist of Lithuanian Diptera. New and Rare for Lithuania Insect Species 18: 16154.

Podènas S. \& Pakalniškis S. 2000. Supplement to the Diptera fauna of Lithuania. Acta Zoologica Lituanica 10 (3): 20-26. https://doi.org/10.1080/13921657.2000.10512332

Ratnasingham S. \& Hebert P.D.N. 2007. BOLD: The Barcode of Life Data System (www.barcodinglife. org). Molecular Ecology Notes 7: 355-364. https://doi.org/10.1111/j.1471-8286.2007.01678.x

Rudzinski H.-G. 1993. Mücken und Fliegen aus dem Schluifelder Moos, Ober-Bayern. Zweite Liste (Diptera: Nematocera: Sciaridae). Entomofauna 14 (16): 281-304.

Salmela J. \& Vilkamaa P. 2005. Sciaridae (Diptera) from central Finland: faunistics and taxonomy. Entomologica Fennica 16: 287-300. https://doi.org/10.33338/ef.84273

Salmela J., Siivonen S., Dominiak P., Haarto A., Heller K., Kanervo J., Martikainen P., Mäkilä M., Paasivirta L., Rinne A., Salokannel J., Söderman G. \& Vilkamaa P. 2015. Malaise-pyynti Lapin suojelualueilla 2012-2014 [Malaise-trapping of insects in conservation areas in Lapland within 20122014]. Metsähallituksen luonnonsuojelujulkaisuja, Sarja A, 221: 1-141.

Shi K., Huang J., Zhang S. \& Wu H. 2014. Taxonomy of the genus Peyerimhoffia Kieffer from mainland China, with a description of seven new species (Diptera, Sciaridae). ZooKeys 382: 67-83.

https://doi.org/10.3897/zookeys.382.4948

Shin S., Lee H. \& Lee S. 2019. Proposal of a new subfamily of Sciaridae (Diptera: Sciaridae), with description of one new species from South Korea. Zootaxa 4543 (1): 127-136.

https://doi.org/10.11646/zootaxa.4543.1.8 
Sutou M., Ito M.T. \& Menzel F. 2004. A taxonomic study on the Japanese species of the genus Sciara Meigen (Diptera: Sciaridae). Studia dipterologica 11 (1): 175-192.

Vilkamaa P. 2014. Checklist of the family Sciaridae (Diptera) of Finland. In: Kahanpää J. \& Salmela J. (eds) Checklist of the Diptera of Finland. ZooKeys 441: 151-164.

https://doi.org/10.3897/zookeys.441.7381

Vilkamaa P. \& Komonen A. 2001. Redescription and biology of Trichosia (Baeosciara) sinuata Menzel \& Mohrig (Diptera: Sciaridae). Entomologica Fennica 12 (1): 46-49. https://doi.org/10.33338/ef.84095

Vilkamaa P. \& Menzel F. 2019. Re-classification of Lycoriella Frey sensu lato (Diptera, Sciaridae), with description of Trichocoelina gen. n. and twenty new species. Zootaxa 4665 (1): 1-67.

https://doi.org/10.11646/zootaxa.4665.1.1

Vilkamaa P., Hippa H. \& Komarova L.A. 2004. The genus Dichopygina gen. n. (Diptera: Sciaridae). Insect Systematics and Evolution 35 (1): 107-120. https://doi.org/10.1163/187631204788964691

Vilkamaa P., Hippa H. \& Heller K. 2013a. Taxonomy of the Sciaridae (Diptera) of Northern Europe: description of eight new species. Studia dipterologica 20 (1): 47-58.

Vilkamaa P., Heller K. \& Hippa H. 2013b. New species of Sciaridae (Diptera) to the Finnish fauna. Sahlbergia 19 (1-2): 20-29.

Vilkamaa P., Hippa H. \& Heller K. 2013c. Review of the genus Camptochaeta Hippa \& Vilkamaa (Diptera, Sciaridae), with the description of nine new species. Zootaxa 3636 (3): 476-488.

https://doi.org/10.11646/zootaxa.3636.3.6

Vilkamaa P., Hippa H. \& Heller K. 2013d. Notes on the taxonomy of the Holarctic Corynoptera Winnertz sensu lato (Diptera, Sciaridae) with description of six new species. Zootaxa 3710 (4): 322-332. https://doi.org/10.11646/zootaxa.3710.4.2

Wu H., Shi K., Huang J. \& Zhang S. 2013. Review of the genus Dolichosciara Tuomikoski (Diptera, Sciaridae) from China. Zootaxa 3745: 343-364. https://doi.org/10.11646/zootaxa.3745.3.3

Manuscript received: 1 November 2019

Manuscript accepted: 6 August 2020

Published on: 8 October 2020

Topic editor: Nesrine Akkari

Desk editor: Radka Rosenbaumová

Printed versions of all papers are also deposited in the libraries of the institutes that are members of the EJT consortium: Muséum national d'histoire naturelle, Paris, France; Meise Botanic Garden, Belgium; Royal Museum for Central Africa, Tervuren, Belgium; Royal Belgian Institute of Natural Sciences, Brussels, Belgium; Natural History Museum of Denmark, Copenhagen, Denmark; Naturalis Biodiversity Center, Leiden, the Netherlands; Museo Nacional de Ciencias Naturales-CSIC, Madrid, Spain; Real Jardín Botánico de Madrid CSIC, Spain; Zoological Research Museum Alexander Koenig, Bonn, Germany; National Museum, Prague, Czech Republic. 